\title{
УПРАВЛІННЯ РОЗВИТКОМ ПЕРСОНАЛУ ПІДПРИЕМСТВА У КОНТЕКСТІ ВПРОВАДЖЕННЯ КОНЦЕПТУАЛЬНОЇ МОДЕЛІ САМОМЕНЕДЖМЕНТУ
}

\section{ENTERPRISE PERSONNEL DEVELOPMENT MANAGEMENT IN THE CONTEXT OF IMPLEMENTATION OF THE CONCEPTUAL MODEL OF SELF-MANAGEMENT}

\author{
Остряніна Світлана Василівна \\ кандидат економічних наук, доцент, \\ Вищий навчальний заклад Укоопспілки \\ «Полтавський університет економіки і торгівлі» \\ ORCID: https://orcid.org/0000-0002-8452-2855 \\ Мокій Олена Олександрівна \\ студентка, \\ Вищий навчальний заклад Укоопспілки \\ «Полтавський університет економіки і торгівлі» \\ ORCID: https://orcid.org/0000-0002-1193-5309

\section{Дробітько Денис Олегович} \\ студент, \\ Вищий навчальний заклад Укоопспілки \\ «Полтавський університет економіки і торгівлі» \\ ORCID: https://orcid.org/0000-0003-3339-933X
}

\section{Ostryanina Svetlana, Mokiy Olena, Drobitko Denys \\ Higher Educational Institution of Ukoopspilka \\ «Poltava University of Economics and Trade»}

\begin{abstract}
У статті розкрито сутність понять «самоменеджмент», «розвиток персоналу». Розглянуто теоретичне підґрунтя концептуальної моделі, що становлять принципи та закони самоменеджменту, які простежуються у діяльності менеджерів. Обґрунтовано, що реалізація стратегії розвитку персоналу має бути узгодженою та в межах загальної стратегії, а також відштовхуватися від тих потреб, можливостей та обмежень, що має підприємство на певному етапі свого функціонування. Доведено, що техніки і технології самоменеджменту $€$ послідовністю етапів, що взаємопов'язані з його основними фрункціями. Для оптимізації процесу розвитку персоналу та оволодіння технологією самоменеджменту запропоновано сучасні методи. Визначено переваги і недоліки щодо їх впровадження. Для активізації розвитку персоналу враховано використання різних фрорм його діяльності та окреслено основні напрями самоменеджменту.
\end{abstract}

Ключові слова: самоменеджмент, розвиток персоналу, концептуальна модель, принципи, закони, фрункції самоменеджменту, методи, методології, технології, фрорми, напрями самоменеджменту.

В статье раскрыто содержание понятий "самоменеджмент», «развитие персонала». Рассмотрены теоретические основы концептуальной модели, состоящей из принципов и законов самоменеджмента, которые наблюдаются в деятельности менеджеров. Обосновано, что реализация стратегии развития персонала должна быть согласована и в рамках общей стратегии, а также отталкиваться от тех потребностей, возможностей и ограничений, которые имеет предприятие на определенном этапе своего орункционирования. Доказано, что техники и технологии самоменеджмента являются последовательностью этапов, которые взаимосвязанны с его основными функциями. Для оптимизации процесса развития персонала и овладение технологией самоменеджмента предложено современные методы. Определены преимущества и недостатки по их внедрению. Для активизации развития персонала учтено использование различных фрорм его деятельности и определены основные направления самоменеджмента.

Ключевые слова: самоменеджмент, развитие персонала, концептуальная модель, принципы, законы, фрунцци самоменеджмента, методы, методологии, технологии, фрормы, направления самоменеджмента. 
The article reveals the essence of the concepts of " self-management", "staff development". The theoretical basis of the conceptual model is considered, which is: the principles and laws of self-management, which are divided into types that are systematized and substantiated by scientists and practitioners within the theory of human behavior. It is revealed that the principles of self-organization and management allow to consciously create conditions for their favorable actions, to predict and predict the development of events, to put forward reasonable and realistic goals of management (building a tree of goals); making management decisions by analyzing the state of the environment, which will determine the urgent need for staff development; assessment of own resource capabilities (constraints) for the development of appropriate strategic goals of the enterprise and personnel development strategy, as well as the needs of the enterprise at a certain stage of its operation. It is proved that the techniques and technologies of self-management are a sequence of stages related to its main functions (goal setting, planning, decision-making, implementation and organization, control, information and communication). For each function, working techniques and methods of implementation are developed, as well as the expected result in the form of a gain in time. Such methods of personnel development as coaching, training, e-learning, case study, self-study, secondment, basket method, have become relevant. All of them are methods of self-management with certain advantages and disadvantages of their implementation. To enhance staff development, the use of various forms of its activities is taken into account, namely: individual; binary method; group; frontal method. The main directions of self-planning (time management; stress management; tim-management (team management); impression management; resource management; life management) that affect not only the process of development and updating the concept of personnel management, but have a tight manner interconnection.

Keywords: self-management, personnel development, conceptual model, principles, laws, functions of selfmanagement, methods, methodologies, technologies, forms, directions of self-management.

Постановка проблеми. Стрімкі зміни в економіці України висувають нові вимоги до якості персоналу підприємства. Наявність тільки кваліфрікаційно-професійних навичок вже не задовольняє вимоги сучасного виробництва, від працівників вимагають швидкого реагування, адаптивності; лояльності та мобільності; готовності відповідати за делеговані повноваження та додаткові навантаження; постійного прагнення до професійного зростання, самовдосконалення як особистих, так і власне ділових якостей; розвитку трудового та інноваційного потенціалу, а також, співробітництва та взаємодопомоги у колективі, підтримки ділової етики та трудової дисципліни.

Аналіз останніх досліджень і публікацій. 3 моменту свого зародження і розуміння самоменеджменту як галузі знань, наукової дисципліни й практичної діяльності багаторазово змінювалося, щоразу здобуваючи більш універсальний, методологічний характер.

3 огляду літературних джерел, поняття «само менеджмент» введено у вживання директором німецького Інституту раціонального використання часу Л. Зайвертом. Він визначав його як цілеспрямоване й послідовне використання випробуваних методів праці в повсякденній практиці, для того щоб оптимально і зі смислом використовувати свій час [3]. У своїх дослідженнях, Майк Вудкок і Дейв Френсіс розглянули особисті обмеження менеджерів у профресійній діяльності, до яких віднесли як зовнішні так і внутрішні фрактори, що негативно впливають на особистісний потенціал і результати праці менеджерів [1].
У свою чергу, концепція Бербель і Хайнц Швальбе зосереджена на проблемах досягнення особистого ділового успіху [10].

У роботі Н.П. Лукашевича [7] запропонована адаптивно-розвиваюча концепція самоменеджменту, яка розкриває внутрішні механізми процесу ділової кар'єри, пояснює його мотивацію, рушійні сили.

Проте зауважимо, що дана проблематика залишається дискусійною і потребує доопрацювання. Усе це зумовлює необхідність систематизації знань та досліджень практичних аспектів управління розвитком персоналу підприємства у контексті впровадження концептуальної моделі самоменеджменту.

Виділення невирішених раніше частин загальної проблеми. Вміле застосовування самоменеджменту як нового напряму у традиційному менеджменті, повною мірою стосується успішного розвитку персоналу, що зумовлений впливом факторів зовнішнього та внутрішнього середовища, результатом організаційних змін, впровадження методик, процесів і ресурсів, необхідних для ефективного виконання поточних і перспективних завдань роботодавця, так і задоволення працівників у самореалізації, профресійній підготовці і кар'єрному зростанні.

Формулювання цілей статті (постановка завдання). Мета статті полягає в обґрунтуванні теоретичних аспектів управління розвитком персоналу підприємства у контексті впровадження концептуальної моделі самоменеджменту.

Виклад основного матеріалу дослідження. Розвиток особистості працівників заснований на тому, що люди з високим рівнем особистої майстерності домагаються вищих результатів. Роз- 
виток організації - це розвиток її працівників. До якостей організації, що навчається, так само відносять здатність до зміни мислення співробітників - співробітників нового типу. Одним 3 перспективних напрямів менеджменту стає самоменеджмент, який $€$ послідовним і цілеспрямованим використанням керівником (менеджером) випробуваних методів і практичних прийомів роботи в повсяқденній діяльності для підвищення ефрективності виконуваних процедур і операцій, досягнення намічених цілей.

Враховуючи завдання, яких необхідно досягти для забезпечення розвитку персоналу організації, можна побудувати комплексну модель самоменеджменту, що містить наступну послідовність дій (рис. 1).

Ґрунтуючись на аналізі різних джерел, підґрунтям концептуальної моделі самоменеджменту є принципи та закони самоменеджменту, які простежуються у діяльності менеджерів, не залежать від їхньої свідомості, волі, бажань.

Ефрективність самоменеджменту пов'язана з тим, наскільки менеджер враховує в своїй діяльності закони самоменеджменту, які визначають його дії, становлення, розвиток. Знання законів самоменеджменту, механізму їхньої дії, фрорми виявлення та використання в процесі життєдіяльності в конкретних умо- вах сприяють ефективному управлінню менеджером собою та підлеглими [12, с. 19].

Усізакони самоменеджментуможнавиокремити у види, що систематизовано та обґрунтовано науковцями і практиками (табл. 1) у рамках теорії трудової поведінки людини.

Принципи випливають із законів, творчо застосовуються в управлінській діяльності залежно від конкретних умов.

До головних принципів самоменеджменту належать:

1. Використання передових досягнень науки самоменеджменту (наявність срундаментальних знань та обізнаність 3 концептуальними основами самоменеджменту).

2. Використання мистецтва самоменеджменту, тобто вміння обмірковувати, передбачати, організовувати й оцінювати результати діяльності, які виявляються у належному соціально-психологічному кліматі організації чи підрозділі, ефективному лідерстві тощо.

3. Використання культури самоменеджменту, який виявляється у ставленні до природи та суспільства. Завдяки самоменеджменту менеджер має змогу визначати засоби організування діяльності (життя) й власного розвитку. Самоменеджмент ґрунтується на системі норм і духовних цінностей.

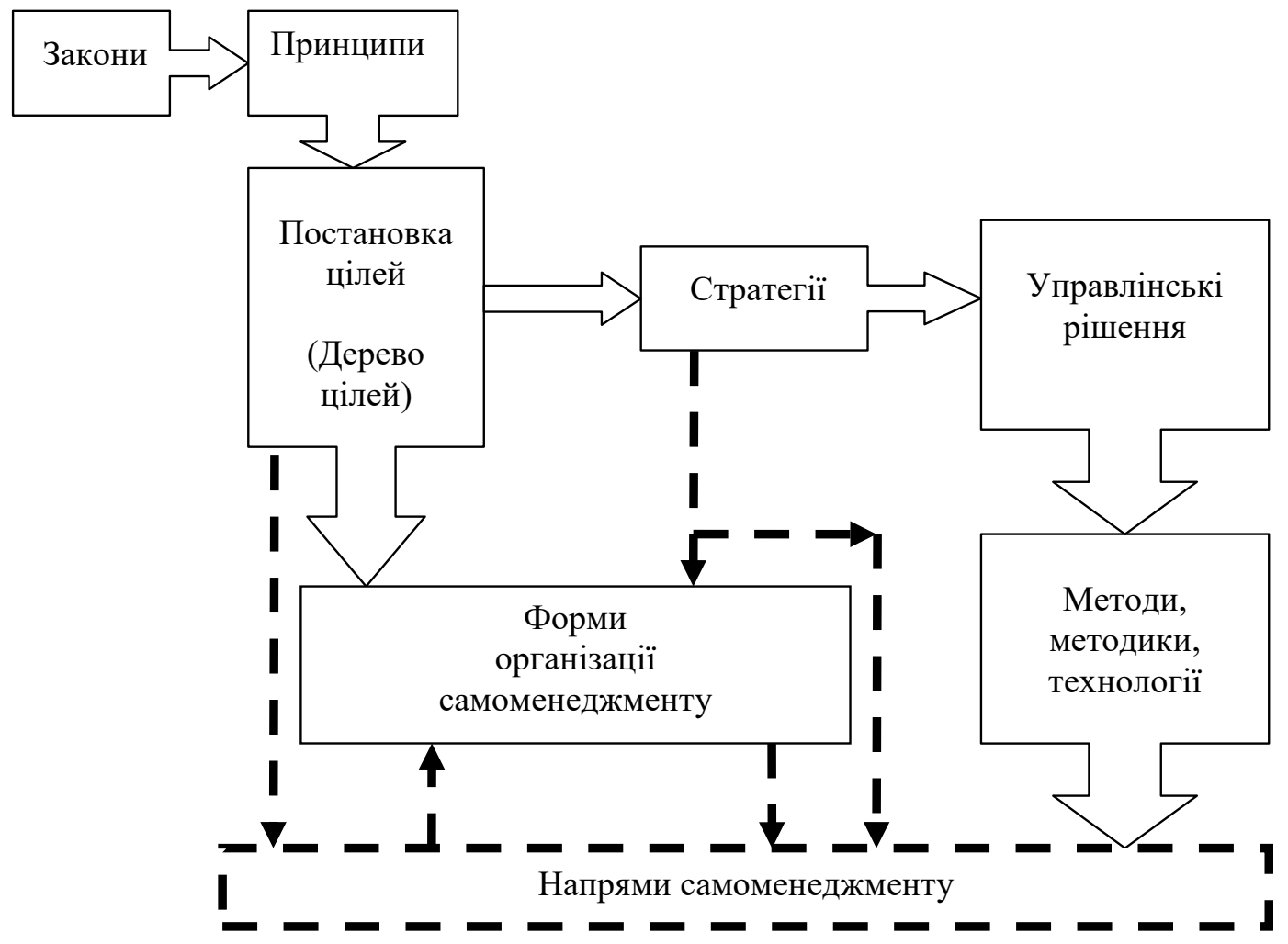

Рис. 1. Управління розвитком персоналу підприємства у контексті впровадження концептуальної моделі самоменеджменту

Джерело: узагальнено авторами на основі [5, с. 30] 
Таблиця 1

Класифікація законів самоменеджменту у рамках теорії трудової поведінки людини

\begin{tabular}{|c|c|}
\hline Види & Сутність \\
\hline \multicolumn{2}{|r|}{ гальні закони поведінки } \\
\hline $\begin{array}{l}\text { Закон єдності свідомого } \\
\text { та несвідомого у поведінці } \\
\text { людини }\end{array}$ & $\begin{array}{l}\text { Дії та вчинки людини визначаються не тільки її ставленням до світу, } \\
\text { мисленням, волею, знанням і розумінням обставин, а й значною } \\
\text { мірою несвідомим: звички, навички, засвоєні соціальні норми }\end{array}$ \\
\hline $\begin{array}{l}\text { Закон єдності біологічного } \\
\text { та соціального в людині }\end{array}$ & $\begin{array}{l}\text { Людина є істотою біосоціальною, iї поведінка залежить як від } \\
\text { умов навколишнього середовища, так і від природних біопсихічних } \\
\text { характеристик }\end{array}$ \\
\hline Закон зворотного зв'язку & $\begin{array}{l}\text { Функціонування системи та її розвиток можливі тільки за наявності } \\
\text { інфрормації, яка надходить з виходу на їі вхід }\end{array}$ \\
\hline $\begin{array}{l}\text { Закон } \\
\text { різнол }\end{array}$ & $\begin{array}{l}\text { Чим складніший об'єкт управління, тим складнішим має бути ор } \\
\text { управління, тим більшим обсягом інфрормації про об'єкт має вол }\end{array}$ \\
\hline $\begin{array}{l}\text { Закон } \\
\text { розвит }\end{array}$ & $\begin{array}{l}\text { Ніщо не може виникнути раніше, н } \\
\text { необхідні передумови }\end{array}$ \\
\hline \multicolumn{2}{|r|}{ Загальні закони поведінки } \\
\hline $\begin{array}{l}\text { Закон кумулятивного впливу } \\
\text { зовнішніх чинників }\end{array}$ & $\begin{array}{l}\text { Дійсною причиною усіх проявів поведінки є не якась одна подія, } \\
\text { а ціла низка подій. Кожна сама собою не дає ефректу, ефрект дає } \\
\text { лише їхнє нагромадження }\end{array}$ \\
\hline носності & $\begin{array}{l}\text { Принципова неможливість опису усієї сукупності чинників, які } \\
\text { детермінують трудову поведінку }\end{array}$ \\
\hline \multicolumn{2}{|r|}{ Закони інерційності людської системи } \\
\hline Закон & Для людини характерним є здатність зберігати набуті якості \\
\hline Ановки & $\begin{array}{l}\text { Поведінка, її цілі, завдання, вибір способу їхнього досягнення } \\
\text { багато в чому залежить від установок людини - здатності } \\
\text { (націленості) діяти у певний спосіб }\end{array}$ \\
\hline \multicolumn{2}{|r|}{ Закони зв'язку з зовнішнім середовищем } \\
\hline $\begin{array}{l}\text { Закон відповідн } \\
\text { зовнішнього сер }\end{array}$ & $\begin{array}{l}\text { Людина виявляє тільки ті якості та реалі } \\
\text { здіб̆ості, яких потребує від неї зовнішнє }\end{array}$ \\
\hline Закон Госсена & $\begin{array}{l}\text { Матеріальн } \\
\text { насичення }\end{array}$ \\
\hline $\begin{array}{l}\text { Закон } \\
\text { Власн }\end{array}$ & $\begin{array}{l}\text { ина має мати можливість володіти, використовувати, розпо- } \\
\text { та присвоювати засоби виробництва і результати своєї праці }\end{array}$ \\
\hline Закон адаптації & $\begin{array}{l}\text { Проявляє } \\
\text { і пристосс }\end{array}$ \\
\hline $\begin{array}{l}\text { Закон випереджаючого } \\
\text { зображення дійсності }\end{array}$ & $\begin{array}{l}\text { Навколишнє середовище відображається у мозку людини не } \\
\text { пасивно, а у динаміці зовнішніх впливів, тенденццій їхнього розвитку. } \\
\text { Поведінка людини базується на передбаченні та прогнозуванні }\end{array}$ \\
\hline $\begin{array}{l}\text { Закон комплексного вп. } \\
\text { на об'єкт управління }\end{array}$ & $\begin{array}{l}\text { Зростання есрективності будь-яких складних систем у разі зміни } \\
\text { лише одного чинника уповільнюється через обмеження, створені } \\
\text { незмінними параметрами }\end{array}$ \\
\hline \multicolumn{2}{|r|}{ Соціально-психологічні закони } \\
\hline Закон соціального & $\begin{array}{l}\text { Людина в процесі життєдіяльності } 3 \\
\text { поколінь і фрормує у такий спосіб св }\end{array}$ \\
\hline Закон соціальної свободи & $\begin{array}{l}\text { юдини залежить від того, наскільки вона володіє } \\
\text { бистого, свідомого, самостійного вибору необхідних } \\
\text { пучення до трудової діяльності й отримання прибутку }\end{array}$ \\
\hline $\begin{array}{l}\text { Закон соціальної } \\
\text { справедливості }\end{array}$ & $\begin{array}{l}\text { Трудова поведінка людини залежить від того, наскільки повно забез- } \\
\text { печує держава, суспільство, колектив пряму залежність соціального } \\
\text { та матеріального добробуту індивіда від його трудової поведінки }\end{array}$ \\
\hline \multicolumn{2}{|r|}{ Біопсихічні закони } \\
\hline $\begin{array}{l}\text { Закон рефрлекторного } \\
\text { характеру діяльності }\end{array}$ & $\begin{array}{l}\text { В основі поведінки людини лежать безумовні й умовні ресрлекси - } \\
\text { закономірні реакції організму на дію зовнішнього середовища }\end{array}$ \\
\hline Закон економії сил & $\begin{array}{l}\text { Людина завжди зацікавлена в отриманні максимального прибутку } \\
\text { на одиницю праці (максимізації виграшу та мінімізації витрат) }\end{array}$ \\
\hline $\begin{array}{l}\text { Закон очікування к } \\
\text { едректу }\end{array}$ & $\begin{array}{l}\text { Людина не може ухвалити та здійснити рішення, яке в майбутньом } \\
\text { не обіцяє ніякого корисного ефректу }\end{array}$ \\
\hline
\end{tabular}

Джерело: узагальнено авторами на основі [5, с. 63-70; 6, с. 13-15] 
4. Використання нагромадженого досвіду самоменеджменту, що становить сукупність знань та умінь менеджера, отриманих і набутих на практиці.

5. Використання єдності фрізичного та духовного розвитку, яка $є$ сутністю менеджера.

6. Персональної відповідальності менеджера за результати діяльності.

7. Поєднання особистих інтересів менеджера та зобов'язань, відповідальність перед організацією (індивідуальних і колективних, особистих і суспільних інтересів).

8. Принцип цілепокладання, формування особистих цілей, цілей розвитку команди працівників.

9. Формування стратегії самоменеджменту, тобто загального плану дій менеджера на майбутнє.

10. Принцип самоорганізації в самоменеджменті.

11. Визначення поведінки у різних ситуаціях відповідно до визначених правил.

12. Принцип есрективності стверджує, що варто проводити дії, які будуть приводити до результатів із найбільшим ефектом [12, с. 20-21].

Отже, досліджена специфріка принципів і законів самоменеджменту дозволяє свідомо створювати умови для їхньої сприятливої дії, передбачати і прогнозувати розвиток подій, висувати обґрунтовані та реальні цілі управління, ухвалювати оптимальні рішення, своєчасно й ефрективно їх реалізовувати. На думку авторів, результатом застосування більшості розглянутих принципів $€$ категорія «розвиток».

Сучасний підхід до визначення розвитку персоналу наводить Іванова-Швець Л. Н. Розглядаючи управління персоналом як стратегічну фрункцію, автор наголошує на тому, що розвиток персоналу виступає інтегральною концепцією, яка, у свою чергу, представлена «...системою взаємопов'язаних дій щодо розробки стратегії, прогнозування та планування потреби у персоналі, управління його кар'єрою та професійним зростанням, організації процесу адаптації, навчання, тренінгу, формування організаційної культури...» [4, с. 54].

Слід зазначити, що прийняття рішення керівництвом підприємства щодо розвитку персоналу повинне бути не тільки узгодженим та відповідати обраній стратегії, а також відштовхуватися від тих потреб, можливостей та обмежень, що має підприємство на певному етапі свого фрункціонування. Тобто, лише шляхом аналізу стану навколишнього середовища, що дозволив виявити актуальність потреби у розвитку персоналу, та оцінки власних ресурсних можливостей (обмежень) розробляється відповідна стратегічним цілям діяльності підприємства стратегія розвитку персоналу.

Реалізація стратегії розвитку персоналу в межах загальної стратегії дозволяє керівникам вітчизняних підприємств впроваджувати системно організований процес безперервного професійного навчання працівників, що дозволить їм на практиці виконувати складні виробничі завдання, підвищувати свій професійно-кваліфрікаційний рівень та дбати про розвиток сприятливої організаційної культури у межах підприємства. При цьому менеджери вищих ланок управління за рахунок аналізу інформаційного забезпечення розвитку персоналу мають можливість самостійно визначати пріоритетні цілі та напрямки розвитку персоналу, обирати необхідні форми навчання та мотивації, скоординовувати працівників на досягнення стратегічних цілей діяльності підприємства [2, с. 68].

В той же час, сучасні ринкові умови змушують шукати керівників нових підходів щодо вирішення управлінських задач. Саме, самоменеджмент оптимізує виконання управлінських фрункцій, що є певною послідовністю етапів, які співзвучні з його основними фуункціями. Для кожної фрункції розроблені робочі прийоми і методи реалізації, а також очікуваний результат у вигляді виграшу в часі. Всі вони складають техніку самоменеджменту (табл. 2) [8, с. 92].

Для оптимізації процесу розвитку персоналу, оволодіння технологією самоменеджменту, доцільним $€$ запровадження сучасних методів, що дозволить керівникам краще зрозуміти логіку процесу самоорганізації у трудовій сорері, більш ефективно керувати роботою підлеглих і давати їм більше можливостей для професійного розвитку (табл. 3).

За нашим переконанням, на зміст і фрорми діяльності персоналу та їх організацію у процесі підготовки і наступного розвитку впливають: цілі та характер розв'язуваних завдань, можливості (економічні, правові (нормативні), тощо) своєї організації та конкурента, особливості ринку, системи управління, організаційна культура, рівень підготовки команди. До таких форм організації самоменеджменту відносяться: індивідуальні - самостійне засвоєння знань, фрормування умінь і навиків, розвиток самооцінки, самостійність і ефективний самоконтроль; бінарні - взаємодопомога, розподіл обов'язків, розвиток відчуття відповідальності за результат спільної діяльності, стимул творчого змагання; групові - спільна організація дій, взаємна оцінка вчинків один 
Таблиця 2

Огляд технік та технологій самоменеджменту

\begin{tabular}{|c|c|c|}
\hline Функція & Методи, техніки роботи & Результат (виграш у часі) \\
\hline Постановка цілей & $\begin{array}{l}\text { Стратегія цілей і методів } \\
\text { досягнення успіху } \\
\text { Знаходження і фрормулювання } \\
\text { цілей } \\
\text { Ситуаційний аналіз }\end{array}$ & $\begin{array}{l}\text { Мотивування } \\
\text { Розпізнавання переваг } \\
\text { Концентрація зусиль на «вузьких } \\
\text { місцях» } \\
\text { Усунення слабких місць } \\
\text { Фіксування термінів і послідовних дій }\end{array}$ \\
\hline Планування & $\begin{array}{l}\text { Принципи тимчасового менеджменту } \\
\text { Стратегічне й оперативне планування } \\
\text { Метод «Альпи» } \\
\text { Система Франкліна } \\
\text { «Пряме» та «зворотне» планування } \\
\text { Ведення «щоденника часу» }\end{array}$ & $\begin{array}{l}\text { Підготовка до реалізації мети (цілі) } \\
\text { Оптимальний розподіл і } \\
\text { планування часу } \\
\text { Скорочення тривалості } \\
\text { проведення заходів }\end{array}$ \\
\hline Прийняття рішень & $\begin{array}{l}\text { Установка пріоритетів } \\
\text { Принцип Парето (Правило «80:20») } \\
\text { АВС-аналіз } \\
\text { принцип Ейзенхауера } \\
\text { Делегування повноважень }\end{array}$ & $\begin{array}{l}\text { Організація праці, що призводить } \\
\text { до успіху } \\
\text { Першочергове вирішення життєво } \\
\text { важливих проблем } \\
\text { Впорядкування завдань відповідно } \\
\text { до їх важливістю } \\
\text { Пріоритетність у справах }\end{array}$ \\
\hline $\begin{array}{l}\text { Реалізація та } \\
\text { організація }\end{array}$ & $\begin{array}{l}\text { Розпорядок дня } \\
\text { Графрік продуктивності } \\
\text { Біоритми } \\
\text { Саморозвиток } \\
\text { Денний робочий план }\end{array}$ & $\begin{array}{l}\text { Застосування принципів } \\
\text { самоменеджменту } \\
\text { Концентрація уваги і зусиль на } \\
\text { значних (першочергових, суттєвих) } \\
\text { завданнях } \\
\text { Використання піку продуктивності } \\
\text { Врахування періодичних коливань } \\
\text { працездатності } \\
\text { Вироблення індивідуального } \\
\text { стилю роботи }\end{array}$ \\
\hline Контроль & $\begin{array}{l}\text { Контролювання результатів } \\
\text { (контроль поставлених цілей, } \\
\text { кінцевий та проміжний контроль) } \\
\text { Контроль протягом дня } \\
\text { (порівняння наміченого і підсумків) } \\
\text { Огляд проведеного дня } \\
\text { (самоконтроль) }\end{array}$ & $\begin{array}{l}\text { Забезпечення виконання } \\
\text { запланованих заходів } \\
\text { Позитивне ведення життя }\end{array}$ \\
\hline $\begin{array}{l}\text { Інорормація і зв'язок } \\
\text { (комунікація) }\end{array}$ & $\begin{array}{l}\text { Раціональні бесіди, наради, } \\
\text { обговорення } \\
\text { Раціональні діалоги (менеджмент } \\
\text { відвідувань) } \\
\text { Раціональне спілкування по телефону } \\
\text { Раціональне ведення кореспонденції } \\
\text { Раціональне читання } \\
\text { Використання чек-листів і } \\
\text { формулярів (планерів) }\end{array}$ & $\begin{array}{l}\text { Краща організація нарад, часу для } \\
\text { переговорів усунення перешкод } \\
\text { Менші перерви в роботі } \\
\text { Більш висока швидкість читання } \\
\text { Менша «паперова війна» }\end{array}$ \\
\hline
\end{tabular}

одного. Фронтальні - кожна особа поперемінно $€$ виконавцем чи керівником, наставником, який підвищує відповідальність за свої знання перед колективом, активізує пізнавальну діяльність, розвиває ініціативність, комунікабельність, працьовитість [12, с. 22].

$\mathrm{Ha}$ наш погляд, сучасна спрямованість самоменеджменту впливає не лише на процес розвитку та оновлення концепції управління персоналом, при цьому пов'язана 3 такими напрями як: тайм-менеджмент - техно- логія раціонального розподілу та підвищення есрективності використання часу; стресменеджмент - сукупність заходів щодо запобігання виникнення стресових ситуацій та реабілітації особистості після їх виникнення, а також зміцнення ії стресостійкості; тім-менеджмент (командний менеджмент) сучасний підхід до створення команди, управління змінами та конорліктами в колективі, підвищення ефрективності командної роботи; імпресіон-менеджмент - технологія фор- 


\section{Сучасні методи розвитку персоналу}

\begin{tabular}{|c|c|c|}
\hline Метод & Переваги & Недоліки \\
\hline Коучинг & $\begin{array}{l}\text { Постійна підтримка тренера; } \\
\text { передача досвіду профресіонала; } \\
\text { розвиток творчого мислення у } \\
\text { персоналу }\end{array}$ & $\begin{array}{l}\text { Ризик перейняти досвід від } \\
\text { недостатньо кваліфрікованого } \\
\text { наставника; недостатня } \\
\text { вмотивованість працівника; } \\
\text { відсутність навчання групи людей }\end{array}$ \\
\hline Тренінг & $\begin{array}{l}\text { Доступність навчання для великих } \\
\text { груп людей; розвиток творчого } \\
\text { потенціалу працівників та групової } \\
\text { взаємодії; поєднання теорії та } \\
\text { практики для вирішення завдань } \\
\end{array}$ & $\begin{array}{l}\text { Відсутня взаємодія з кожним } \\
\text { учасником; недостатність отримання } \\
\text { повної інформації за один тренінг; } \\
\text { обмежена кількість групи для } \\
\text { кращого засвоєння інфрормації } \\
\end{array}$ \\
\hline E-learning & $\begin{array}{l}\text { Навчання великої групи людей; } \\
\text { швидкість отримання великої } \\
\text { кількості інфрормації; високий рівень } \\
\text { вмотивованості працівника } \\
\end{array}$ & \begin{tabular}{|l|} 
Ризик отримання недостовірної \\
індормації; виникнення труднощів \\
з опрацюванням інформації; \\
відсутність групової взаємодії \\
\end{tabular} \\
\hline Кейс-стаді & $\begin{array}{l}\text { Розвиток групової взаємодії; } \\
\text { розвиток головних здібностей та } \\
\text { навичок працівників; використання } \\
\text { теоретичних знань на конкретному } \\
\text { завданні }\end{array}$ & $\begin{array}{l}\text { Відсутня спрямованість на розвиток } \\
\text { навичок окремого працівника; } \\
\text { можливість домінування думки } \\
\text { найактивнішого учасника та } \\
\text { нівелювання суджень інших } \\
\end{array}$ \\
\hline Самонавчання & $\begin{array}{l}\text { Високий рівень вмотивованості; } \\
\text { багатогранний розвиток особистості; } \\
\text { розвиток саме тих навичок і вмінь, що } \\
\text { потрібні працівнику }\end{array}$ & \begin{tabular}{|l|} 
Ризик отримання застарілої та \\
недостовірної інфрормації; ризик \\
втратити мотивацію у випадку \\
невдачі; доступність лише для \\
цілеспрямованих та рішучих людей \\
\end{tabular} \\
\hline Secondment & $\begin{array}{l}\text { Переймання досвіду, ведення } \\
\text { кадрової діяльності в іншій компанії; } \\
\text { освоєння нових навичок, потрібних } \\
\text { для працівника; швидка адаптація до } \\
\text { іншого середовища }\end{array}$ & $\begin{array}{l}\text { Психофрізіологічне навантаження } \\
\text { на працівника; складність у } \\
\text { пристосуванні до нового середовища; } \\
\text { комунікативні бар'єри з новим } \\
\text { керівництвом }\end{array}$ \\
\hline Баскет-метод & $\begin{array}{l}\text { Розвиток навичок і вмінь, } \\
\text { які необхідні для конкретної } \\
\text { посади; швидке виявлення } \\
\text { готовності працівника до посади; } \\
\text { вмотивованість та бажання } \\
\text { працівника отримати посаду }\end{array}$ & $\begin{array}{l}\text { Складність узагальнення даних і } \\
\text { перевірка поставленого завдання; } \\
\text { спрямованість на індивідуальний } \\
\text { розвиток потенціалу працівника; } \\
\text { значні затрати часу на підготовку } \\
\text { завдання }\end{array}$ \\
\hline
\end{tabular}

\section{Джерело: [11, с. 442]}

мування позитивного враження про себе; сукупність методів та принципів фрормування свого привабливого іміджу; ресурс-менеджмент - вміння особи виявляти компетентність у саморозвитку; лайср-менеджмент - нова система технологій в управлінні власним життям: цілями та завданнями, фрінансами і часом, емоціями та здоров'ям, комунікацією та відносинами тощо [9, с. 171].

Висновки. Дослідження показали, що для результативного впровадження концептуальної моделі самоменеджменту необхідно виконувати декілька основних правил: враховувати в процесі управління і організації розвитку персоналу на підприємствах закони і принципи самоменеджменту, що визначають його дії, становлення, розвиток; правильно визначити мету, що сприятиме чіткій уяві про результат та забезпечить взаємозв'язок цілей (побудову дерева цілей); планувати використання свого часу для досягнення поставлених цілей; приймати управлінські рішення шляхом аналізу стану навколишнього середовища, що дозволить виявити актуальність потреби у розвитку персоналу; провести оцінку власних ресурсних можливостей (обмежень) для розробки відповідної стратегічним цілям діяльності підприємства та стратегії розвитку персоналу; для забезпечення максимального ефекту доцільно використовувати методи, методики та технології самоменеджменту; враховувати орорми організації самоменеджменту; запроваджувати нові напрями самоменеджменту не лише для професійного і особистого розвитку персоналу, але і для сприяння подальшого розвитку підприємства вцілому. 


\section{СПИСОК ВИКОРИСТАНИХ ДЖЕРЕЛ:}

1. Вудкок М., Френсис Д. Раскрепощенный менеджер. Москва : Дело, 1991. 320 с.

2. Грузіна І.А., Дериховська В.І. Проблеми розвитку персоналу в системі стратегічного управління підприємством : монографрія. Харків : ХНЕУ ім. С. Кузнеця, 2014. 252 c.

3. Зайверт Л. Ваше время - в Ваших руках: советы деловым людям, как эфффективно использовать рабочее время / пер. с нем. Москва : Интерэксперт ; Инфрра-М, 1995. 267 с.

4. Иванова-Швец Л.Н., Корсакова А.А., Тарасова С.Л. Управление персоналом : учеб.-метод. комплекс. Москва : Изд. Центр ЕАОИ, 2008. 200 с.

5. Колпаков В. М. Самоменеджмент : навч. посіб. Київ : ДП «Видавничий дім «Персонал», 2008. 528 с.

6. Лугова В.М., Голубєв С.М. Основи самоменеджменту та лідерства : навч. посіб. Харків : ХНЕУ ім. С. Кузнеця, 2019. $212 \mathrm{c}$.

7. Лукашевич М.П. Теорія і практика самоменеджменту. Київ : МАУП, 2010. 225 с.

8. Остряніна С.В. Самоменеджмент і тайм-менеджмент. Дистанційний курс. Полтава : ПУЕТ, 2020. URL: http://www2.el.puet.edu.ua

9. Остряніна С.В., Дробітько Д.О., Мокій О.О. Управління розвитком персоналу підприємства у контексті впровадження сучасних технологій самоменеджменту. Інформаційні технології: наука, техніка, технологія, освіта, здоров'я : матеріали XXIX Міжнар. наук.-практ. конфр. МicroCAD-2021, м. Харків, 18-20 травня 2021 р. Харків, Ч. ІІІ / за ред. проф. Сокола Є.І. НТУ «ХП|». 311 с.

10. Швальбе Б., Швальбе Х. Личность, карьера, успех. Психология бизнеса. Москва : Прогресс, 1993. 240 с.

11. Шелюжак І.Г., Тодорюк С.І., Кифяк В.І. Інноваційні методи розвитку персоналу. Бізнес Інфрорм. 2020. № 3. C. 437-444. URL: https://doi.org/10.32983/2222-4459-2020-3-437-444

12. Юринець 3.В., Макара О.В. Самоменеджмент : навч. посіб. Львів : ЛНУ імені Івана Франка, 2014. 272 с.

\section{REFERENCES:}

1. Vudkok, M. \& Frensys, D. (1991) Raskreposhhennyj menedzher. Dlya rukovoditelya-praktika [Unfettered manager. For practical manager]. Moscow: Delo, 320 p. (in Russian)

2. Hruzina I.A., \& Derykhovska V.I. (2014) Problemy rozvytku personalu v systemi stratehichnoho upravlinnia pidpryiemstvom [Problems of personnel development in the system of strategic management of the enterprise]: monohrafiia. Kharkiv: KhNEU im. S. Kuznetsia, 252 p. (in Ukrainian)

3. Zajvert, L. (1995) Vashe vremya - v Vashyh rukakh [Your time - in your hands]. Moscow: Intereksport, $267 \mathrm{p}$. (in Russian)

4. Yvanova-Shvets L.N., Korsakova A.A., \& Tarasova S.L. (2008) Upravlenye personalom:ucheb.-metod. kompleks [Personnel management]. Moscow: EAOY, 200 p. (in Russian)

5. Kolpakov, V. (2008). Samomenedzhment [Self-management]. DP «Vydavnychyj dim «Personal». Kyiv, 528 p. (in Ukrainian)

6. Luhova V.M., Holubiev S.M. (2019) Osnovy samomenedzhmentu ta liderstva [Fundamentals of self-management and leadership]: navch. posib. Kharkiv: KhNEU im. S. Kuznetsia, 212 p. (in Ukrainian)

7. Lukashevych, M. P. (2010) Teoriia i praktyka samomenedzhmentu [Theory and practice of self-management]. Kyiv: MAUP, 225 p. (in Ukrainian)

8. Ostryanina S.V. (2020) Samomenedzhment i taim menedzhment: navchalnyj posibnyk [Self-management end time management]: Dystantsiinyi kurs. Poltava: PUET. Available at: http://www2.el.puet.edu.ua (in Ukrainian)

9. Ostrianina S.V., Drobitko D.O., \& Mokii O.O. (2021) Upravlinnia rozvytkom personalu pidpryiemstva u konteksti vprovadzhennia suchasnykh tekhnolohii samomenedzhmentu [Management of enterprise personnel development in the context of introduction of modern technologies of self-management]. Informatsiini tekhnolohii: nauka, tekhnika, tekhnolohiia, osvita, zdorovia: materialy XXIX Mizhnar. nauk.-prakt. konf. MicroCAD-2021, m. Kharkiv, 18-20 travnia 2021 r. Kharkiv, Ch. III / ed. prof. Sokola Ye.I. NTU «KhPI», 311 p. (in Ukrainian)

10. Shvalbe B., \& Shvalbe Kh. (1993) Lychnost, karera, uspekh. Psykholohyia byznesa [Personality, career, success. Business Psychology]. Moscow: Progress, 240 p. (in Russian)

11. Shelyuzhak, I., Todoriuk, S., Kyfyak, V. (2020) Innovative Methods of Staff Development. [Innovative methods of personnel development]. Business Inform, pp. 437-444. Available at: https://doi.org/10.32983/2222-4459-2020-3437-444 (in Ukrainian)

12. Yurynec, Z. \& Makara, O. (2014) Samomenedzhment: navchalnyj posibnyk [Self-management: study guide]. Lviv: LNU imeni Ivana Franka, 272 p. (in Ukrainian) 